\title{
CULTURE, CARBON, AND CLIMATE CHANGE: A CLASS ANALYSIS OF CLIMATE CHANGE BELIEF, LIFESTYLE LOCK-IN, AND PERSONAL CARBON FOOTPRINT
}

\author{
Jean Léon Boucher
}

\author{
Stony Brook University \\ 100 Nicolls Rd, Stony Brook, NY 11794, USA \\ e-mail: JLB964@gmail.com
}

\begin{abstract}
Global climate change is arguably the defining issue of the present age, and high carbon emissions are the major cause of this change. Prior research has shown that carbon emissions are strongly positively associated with household incomes - both in a given nation and between nations. Scholars explain that one of the root causes of this "income-carbon" relationship is lifestyle lock-in: the inability of individuals to change their consumption habits - due to institutionalized structures, contexts, and norms. Using a United States nationally representative dataset $(N=2107)$, I test whether climate change beliefs moderate the income-carbon relationship (emissions were only examined for personal mobility and dietary carbon footprints). I found a significant positive correlation between climate change beliefs and personal carbon footprints only among one segment of the public - those who are most concerned about climate change (18\% of the sample). I also reaffirm the significant positive correlation between household income and carbon emissions - income was the most dominant predictor variable in my analyses. I call for taxes and limits on both income and carbon emissions.
\end{abstract}

Keywords: personal carbon footprint, environmentally significant behavior, attitude-behavior gap, lifestyle lock-in, climate change belief

\section{INTRODUCTION}

Climate scientists warn that human activities - primarily in the area of carbon emissions and the burning of fossil fuels - have tipped the planetary climate "off balance". There are also reports of impending environmental catastrophes and extreme costs if the current climate imbalance is not remedied. In this study, I examine the income-carbon relationship - the established significant association between personal income, personal consumption behaviors, and resultant carbon emissions (i.e. the way humans consume in relation to their income) - and I test whether climate change belief can moderate this relationship. My country of research is the United States and I use a broad, nationally representative, climate change belief construct to test possible moderating effects. As informed by the literature, I hypothesize that, due to normative and structural constraints, climate change belief would not moderate the income carbon relationship. 
In my results, I reject the null hypothesis as survey respondents with the strongest climate change beliefs did slightly moderate the income-carbon relationship. Though this moderation affect does exist, it is only slight, while income - as elaborated in the literature - is the most dominant independent variable in my analyses. In this paper, I review the pertinent literature, present my data and research methodology, discuss my findings and conclude with recommendations.

This study is based on a cultural approach; my interest is in how individual attitudes and actions might assist in efforts to mitigate global climate change. However, like other scholars, I believe a more structural institutional level approach - as opposed to cultural / individual - is most effective for reducing carbon emissions related to human activities.

\section{REVIEW OF THE LITERATURE}

In light of the looming crisis of climate change (IPCC, 2014a; Melillo et al., 2014; Zalasiewicz et al., 2015), there is a wave of scholarship directed at trying to understand and change human-environmental attitudes and behaviors, especially carbon-emissions related behaviors (Brulle, 2010; Dietz et al., 2009; Maibach et al., 2008; McCright, 2009; McKenzie-Mohr, 2011). ${ }^{1}$ However, with respect to carbon emissions, they are not emitted equally by all persons (Hertwich and Peters, 2009): a great majority originates from people with higher levels of income and more industrialized nations (Chichilnisky and Heal, 1994; IPCC, 2014b; Munasinghe, 2010; World Bank, 2015).2, 3

A number of studies have analyzed the distribution of greenhouse gas emissions (GHGEs) within industrialized nations and found they are positively correlated with personal income (Dey, 2010; Druckman and Jackson, 2009; Ummel, 2014; Wilson et al., 2013). ${ }^{4}$ Thus, as income is known to be distributed unequally, there are also carbon emission inequalities (Chancel, 2014; Ummel, 2014). In the U.S., K. Ummel (2014) observed that "the top $20 \%$ of polluters account for $40 \%$ of all GHG pollution...

1 The terms GHGs, carbon, carbon footprint, $\mathrm{CO}_{2}$ and $\mathrm{CO}_{2} \mathrm{e}$ are used synonymously: they refer to the emitted greenhouse gases and carbon dioxide $/ \mathrm{CO}_{2}$ equivalents emitted during any part of the human extraction, processing, production, distribution, consumption, or dumping of a product / good.

2 Though there is a global shift toward lower income countries as the dominant source points of greenhouse gases (embodied in products, consumption, and international trade), consumers in industrialized countries remain the primary end users of this embodied carbon (Caldeira and Davis, 2011; Davis and Caldeira, 2010; Peters et al., 2011).

3 Analyses of the environmental impacts of affluent versus poorer countries are not new (Ehrlich and Holdren, 1971).

4 Income-carbon correlations have been found in the United States (Jones and Kammen, 2014; Ummel, 2014), the United Kingdom (Druckman and Jackson, 2008, 2009), Australia (Dey, 2010; Lenzen and Murray, 2001), Canada (Wilson, Tyedmers, and Spinney, 2013), and The Netherlands (Gatersleben et al., 2002). 
[while] the lowest-emitting $40 \%$ of the population (largely individuals in lower income groups) are responsible for just 20\%" (2014:12). ${ }^{5}$

When attempting to explain the causes of these economically stratified and geospatially dispersed GHGEs, scholars tend toward two explanations: consumer lifestyle and "lockin". Lifestyle is a term which identifies and classifies group behaviors, expenditures, and energy use patterns (Bin and Dowlatabadi, 2005; Schipper et al., 1989; Weber and Perrels, 2000). ${ }^{6}$ Some scholars explain lifestyle as the outcome of individuals just trying to meet their needs and wants (Druckman and Jackson, 2009), and high emissions associated with higher income groups reflect desires for more goods, services, luxuries, and comforts (Zhang et al., 2015:6). Observing this income / lifestyle / energy-use relationship, Gatersleben et al. posit that "as soon as people have the financial ability to perform the behavior, they are tempted to do so" (2002:354). Sanne (2002:280) presents a similar view with what he calls the "ratchet effect": the more money people have, the more they buy, and the more they buy, the more money they need to support themselves.

"Lock-in", the other predominant explanation for the stratification of GHGEs - not to be considered separate from lifestyle as much as part of it - is best defined as cultural and structural constraint. These constraints are generally explained as institutionalized structures, contexts, and norms (Chancel, 2014; Guagnano et al., 1995; Jackson, 2005; Sanne, 2002; Thogersen, 2005). ${ }^{7}$ Druckman and Jackson (2009) assert that it is difficult to change both individual and institutional norms and, by extension, it is the affluent who should be targeted with new policies. Druckman and Jackson (2009) also allude to more than one type of lock-in: one which is more institutional / structural and the other more normative / cultural. ${ }^{8}$

This dichotomizing of strategies (cultures versus structures and individuals versus institutions) to assuage the planetary impacts of human behavior is supported by others; although structural / institutional level changes are seen as the most effective approach to climate change mitigation (IPCC, 2014a; Princen et al., 2002; Szasz, 2011), lifestyle and personal behaviors are also a key area for research and intervention (Dietz et al., 2009; Nagel et al., 2010; Tucker, 1978). Moreover, at this critical historical juncture, it appears that what can be done, should be done.

5 Studies have also found that geospatial distribution (urban, suburban, rural) and population densities are also important determinants of GHGEs (Jones and Kammen, 2014; Ummel, 2014). Zhang et al. (2015), Lyons et al. (2012), and Fahmy et al. (2011) report similar findings in China, Ireland, and the United Kingdom respectively.

6 Additionally, lifestyle can also include residence location, family size, age cohort, and size of house or apartment (Chancel, 2014).

7 Sanne (2002) asserts that people are not happy to be constrained by their circumstances, but feel lockedin.

8 The phenomenon of a finite planet itself presents a third type of lock-in, a biophysical one. Therefore, a possible "collision of lock-ins" can be theorized. 


\subsection{Probing Climate Change, Lifestyles, and Cultural Lock-In}

In light of this global climate urgency, I attempt to dig deeper into human behavioral norms, the issue of lock-in, and consumption lifestyles by researching at the individual level with a cultural perspective. I also intend to ground my approach sociologically and in a class cultural perspective (Bourdieu, [1979]1984). This means that lifestyles are not considered benign, arbitrary phenomena, but are inculcated from childhood, as an individual habitus - an unconscious system of predispositions - in relation to certain socio-economic fields with respect to one's specific class fraction and conditions of existence. Practically, then, individuals from distinct classes will be inclined to remain culturally "stationary" i.e. locked-in - with respect to their inculcated predispositions which match them to certain positions in social space. This theoretical approach, then, suggests that not only might there be an income-carbon relationship, but also a relationship between class culture and carbon emissions, as might be deduced from Bourdieusian theory ([1979]1984).

Concerning attitudes about climate change, as a minority of people in the United States believe that climate change is both occurring and human-caused (Guber, 2013; Leiserowitz et al., 2012; Nisbet and Myers, 2007). I am interested in how awareness of climate change may affect behavior; specifically, the relationship between an individual's climate change belief and GHGEs. ${ }^{9}$ I am also interested in examining, while controlling for income, any changes in environmentally significant behavior - via estimations of GHGEs - with respect to one's belief in anthropogenic (human-caused) climate change (ACC). ${ }^{10}$

It must be noted that there is an important methodological distinction upon which I am building: pro-environmental behavior versus environmentally significant behavior. ${ }^{11}$ In response to much research on pro-environmental behavior, of which findings are dominated by survey data and self-reports (Capstick et al., 2015; Diamantopoulos et al., 2003), environmentally significant behavior has emerged. ${ }^{12}$ In this new development,

9 In 2012, Leiserowitz et al. reported that only 38\% of their sample agreed that global warming was both happening and mostly human-caused; with such a split in the U.S. between "believers" and "non-believers", this is an opportune time to explore these phenomena.

10 The term belief - and other terms related to it - such as non-belief, disbelief, believers or deniers - may be seen to invoke a type of religious discourse or dynamic in a debate over climate science. However, use of the term belief in this study refers to the affirmative response of survey participants to a question such as, "Do you think that global warming [or climate change] is happening? Yes, No, or I don't know". In response, there are people who think climate change is happening, those who think it is not, and those who "do not know".

11 Over the years, different scholars have used different synonyms for pro-environmental behavior: environmentally responsible (Fransson and Gärling, 1999; Hines et al., 1987), friendly (Gärling et al., 2009; Haustein and Hunecke, 2007), or sustainable behavior (Griskevicius et al., 2012; Kurz, 2002; McKenzieMohr, 2011), and also conservation (Kaiser et al., 2005; Schultz et al., 2005), or ecologically conscious behavior (Ellen et al., 1991; Roberts and Bacon, 1997).

12 Besides critiquing the dominance of polling data in the literature, Capstick et al. (2015) also identify a lack of consistency in the construction of belief measures and call for an increase in qualitative research. 
scholars have focused on identifying and quantifying actual environmental impacts as distinct from self-reported environmental behaviors (Clements et al., 2015; Martiskainen, 2007; Stern, 2000b). It is not so much that research on environmentally significant behavior foregoes all self-reported behavior as much as it focuses on the actual material / environmental impacts of such reports. ${ }^{13}$ In this present study, my interest is in environmentally significant behavior, but first I will review the research on climate change belief.

\subsection{Climate Change Belief}

There is actually not a lot of research on the relationship between climate change attitudes and environmentally significant behavior. ${ }^{14}$ When strictly analyzing attitudes on climate change, though, some scholars have identified a debate embedded in oppositionally poised cultural worldviews - hierarchical individualists versus egalitarian communitarians: attitudes that preexist in respondents (Kahan et al., 2012). These worldviews undergird much of the debate on ACC and are found to be the strongest predictors of perceptions of climate change risk (Kahan et al., 2012). Thus, these scholars assert that it is preexisting worldviews - not a lack of information, scientific understanding, or even political orientation - that most strongly determine climate change attitudes. ${ }^{15}$ Other studies have also found survey responses oppositionally polarized, but over political ideology and party lines (Dunlap and McCright, 2008; Guber, 2013; Leiserowitz et al., 2011, 2012; Perkowiz et al., 2014). Additionally, Leiserowitz et al. (2009) identified six respondent groups / segments: Alarmed, Concerned, Cautious, Disengaged, Doubtful, and Dismissive. Figure 1 below displays these segments for the fall of 2008, with their respective population distributions represented by the size of each sphere. ${ }^{16}$ The questioning schemes that determine these different segments range from belief about global warming to risk perceptions, degree of worry, reported energy use behaviors, and preferences with respect to possible societal responses (Maibach et al., 2011). Though there

13 For a review of this literature, see Osbaldiston and Schott (2012).

14 Most of the existing literature examines self-assessed respondent behaviors, but aside from climate change, scholars have long studied consumption patterns and have tried to understand their relationship to demographic indicators, ecological attitudes, and environmental concern (Balderjahn, 1988; Jones and Dunlap, 1992; Kassarjian, 1971; Shove, 2003; Stern, 2000a). However, the relationship between environmental and climate attitudes is still being explored, i.e. although ACC alarm has grown (Melillo et al., 2014) with some fluctuations, attitudes and environmental concern - both nationally and internationally - have remained stable (Franzen and Vogl, 2013; Jones and Dunlap, 1992).

15 Kahan et al. (2012:733) define this dynamic as cultural cognition: "the conforming of beliefs to the ones that predominate within one's group". Thus, when they were expecting one's scientific literacy to increase perceived risk, they instead found a polarized split in accordance with one's groups' individualist or communitarian worldview.

16 Though there are more recent and up-to-date findings on climate change belief segmentation in the US, data from 2008 is presented because this is the year that the (carbon calculable) behavioral questions I analyze were asked. 
is some variation demographically, the six segments are not very different: the strongest predictor variable of segmentation is political orientation, e.g., whether a respondent is more liberal, conservative, Republican, Democrat, Independent or other. Liberals are more inclined to the population segments to the left (of Figure 1) and conservatives more to the right. Thus, the literature posits that asking someone their beliefs about climate change will reveal more than just beliefs; it is akin to asking, "What is your ideological tribe?" Additionally, these beliefs and these "tribes" invoke grander institutional narratives and culturo-politico-economic tensions between groups with different views on nature and fairness (Douglas et al., 1998; Rayner and Malone, 1998). In the words of Rayner and Malone (1998:24), the "...debate about climate change is often a surrogate for a broader, so-far intractable political discourse about population, lifestyles, and international development".

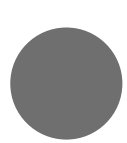

Alarmed

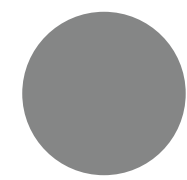

Concerned $33 \%$

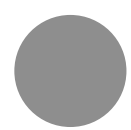

Cautious
$19 \%$

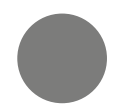

Disengaged $12 \%$
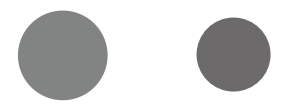

Doubtful $11 \%$
Dismissive $7 \%$

Highest Belief in Global Warming Most Concerned

Lowest Belief in Global Warming

Most Motivated

Least Motivated

Figure 1. Six Americas adult population segmentation (Leiserowitz et al., 2009:3)

There are also other studies that suggest a socioeconomic connection to ACC belief. During the recession of 2008, economic concerns prevailed with studies detecting a decline in ACC belief (Newport, 2010; Pew, 2009; Saad, 2009). Postmaterialist / prosperity arguments posit that there exists a well-educated, left-leaning middle-class with the time and ability to be concerned about ecological issues (Franzen and Meyer, 2010; Inglehart, 1990). ${ }^{17}$ There are mixed findings on such a thesis, with some scholars finding evidence of a somewhat stable cultural field of ecological views and practices expanding across class boundaries (Carfagna et al., 2014; Laidley, 2013) - what Carfagna et al. (2014) call an eco-habitus - while other scholars find little or no "prosperity" tendencies:

17 Seemingly confirming this argument, at the international level there is evidence of greater environmental concern in wealthier countries (Franzen and Vogl, 2013), but when using different measures, there is evidence that finds relations between wealth and environmental concern inconclusive (Dunlap and York, 2008). 
(i) in countries with higher levels of income inequality (Dolenec et al., 2014), or (ii) when respondents consider the trade-offs between economic growth and environmental protection (Domazet et al., 2014). Furthermore, other scholars find that those of higher classes are more politically engaged on climate issues (Dietz et al., 2007; Leiserowitz et al., 2012; McCright, 2009). Nevertheless, these studies are primarily attitudinally focused and do not assess actual respondent behaviors or their ecological impacts. Therefore, it might be assumed that an increase in environmental concern does reduce environmental impacts, but this specific relationship - at least in these studies - was not measured.

\subsection{Attitude-Behavior Gap}

Although scholars have long examined the environmental attitude / behavior relationship (Diamantopoulos et al., 2003; Osbaldiston and Schott, 2012), when it comes to assessing environmentally significant behavior, the literature shows that the effects of an individual's concern for the environment are annulled by the effects of their income (Csutora, 2012; Gatersleben et al., 2002; Wilson et al., 2013). ${ }^{18}$ Therefore, scholars assert that even if the affluent have high levels of environmental concern, they still use more energy and emit more GHGs than their lower income counterparts. Furthermore, when compared to those similarly situated socioeconomically, there is no comparable difference in ecological impact between those with high or low levels of environmental concern. This is the attitude-behavior gap (A-B gap): the general inability, all along the socio-economic hierarchy, of ecological consciousness to significantly reduce human impacts on the environment. ${ }^{19}$ In other words, the A-B gap is present when self-reported behaviors do not align with self-reported attitudes (Blake, 1999; Hoggett, 2013; Kollmuss and Agyeman, 2002; Whitmarsh et al., 2011). ${ }^{20}$

18 These particular studies, though, were not conducted in the U.S. - Csutora (2012) in Hungary, Gatersleben et al. (2002) in the Netherlands, and Wilson et al. (2013) in Nova Scotia, Canada - nor did they specifically focus on climate change attitudes; this is the underdeveloped area of research that I plan to explore. 19 Csutora (2012) found that there is less variance in the ecological footprint for individuals of lower income. This may be reflective of Bourdieu's ([1979]1984) concept of proximity to necessity and limited lifestyle options. Relatedly, Whitmarsh (2009:13) observed that "those who take action to conserve energy generally do so for reasons unconnected to the environment (e.g., to save money)".

20 Verplanken (2011) asserts that in light of the A-B gap researchers should strictly focus on changing behaviors and disregard changing attitudes. Lertzman (2013) questions the whole existence of a gap, arguing that it is an outcome of shortcomings in measures and the oft contradictory and illusive nature of the human subject itself. Others add that measures of environmental attitudes are often inflated as they are rarely ranked alongside other personal and social concerns (Guber, 2013), i.e. relative to one's economic priorities or a "pool of worry" (Linville and Fischer, 1991). Some assert - in accord with cultural lock-in - that social norms obstruct an individual's ability to behave in accord with their attitudes (Newhouse, 1990). To be clear, the idea that there is a gap between self-reported and actual behavior is not new (LaPiere, 1934; Schuman and Johnson, 1976; Wicker, 1969). Additionally, the A-B gap is reminiscent of a number of adages: the spirit is willing but the flesh is weak; actions speak louder than words; walk the talk; put your money where your mouth is, etc. 


\section{RESEARCH DESIGN}

In light of this literature, I conducted this study in the United States and used ACC belief as an indicator of environmental awareness. I tested ACC belief against GHGEs calculations for mobility / transportation and dietary behaviors / carbon-footprints. ${ }^{21}$ This specific combination of factors is unique in literature. ${ }^{22}$ Additionally, in light of the phenomena of lock-in, the A-B gap, and my hypothesis, moving forward - reflective of the literature that attitudes on climate change will not moderate the effects of income on carbon emissions, I decided: (i) to use the strongest form of climate change belief available - that survey respondents perceive climate change as human-caused (anthropogenic) and dangerous (they are deeply concerned about it and report that they have changed some of their behaviors because of it), and (ii) since Jones and Kammen (2011) report that changes in mobility and dietary footprint behaviors have the highest potential to abate carbon emissions (comparatively low upfront "costs" versus the subsequent GHGE reductions), that I will only analyze respondent mobility and dietary footprints. Thus, to be clear, my research question is, "Does ACC belief play a moderating role in the income-carbon relationship?" and my hypothesis - in accordance with the literature - is that it does not.

\section{METHODS}

For the U.S. research, I used the weighted, nationally representative dataset Climate Change in the American Mind survey (CCAMS; N=2107). ${ }^{23}$ The 2008 CCAMS has specific carbon calculator inputs from car ownership (year, make, model, and usage), air travel, and dietary type. ${ }^{24}$ These carbon calculations were analyzed both separately and

21 The terms mobility and transportation are used synonymously.

22 Even though studies have examined the socio-economic distribution of carbon emissions in the U.S. (Jones and Kammen, 2014; Ummel, 2014) and third party carbon calculators that are publicly available (Lynas, 2007; Padgett et al., 2008), as well as numerous studies (in the US) on the public distribution of climate change belief and risk perceptions (Guber, 2013; Howe et al., 2015; Leiserowitz et al., 2012, 2014; Leiserowitz and Feinberg, 2005), a combined analysis of carbon calculations in relation to climate change belief is not present in the literature.

23 This ongoing nationally representative survey has been the source of various research and reports - see the Yale (2015) website. Amongst other things, this survey tracks and examines public understanding of climate change in the U.S.: its causes, how risks are perceived, and possible consequences. For more detail, see Maibach et al. (2011:7-8).

24 Air travel calculations were based on four questions which queried (1) how many short distance (up to 300 miles), (2) medium distance (between 300 and 1,000 miles), (3) long distance (between 1,000 and 3,000 miles), or (4) overseas flights a respondent "usually takes each year". Dietary carbon calculations were based on respondent dietary type, i.e. plant-based (vegetarian, vegan) or meat-based (i.e. omnivore). This data was used in conjunction with different recommended dietary guidelines by respondent age and gender (USDA, 2010; USDA-ERS, 2014). 
added into one mobility-dietary footprint - a total yearly rate of GHGEs per person (kg$\mathrm{CO}_{2}$ e/adult-yr) - the primary dependent variable in my analyses. Lifestyles were operationalized as personal GHGEs, i.e. carbon lifestyles, but in a reduced mobility-dietary version. In operationalizing ACC belief, I utilized the Six Americas belief segmentation as provided by the CCAMS (Maibach et al., 2011), and these ACC beliefs are segmented into six types: Alarmed, Concerned, Cautious, Disengaged, Doubtful, and Dismissive. ${ }^{25}$ The concept of lock-in - a main theme of this research - was examined relationally as the correspondence between household income and the mobility-dietary footprint see Figure 2 below. ${ }^{26}$ This relationship was tested to examine the degree to which it is moderated by ACC belief. ${ }^{27}$ Finally, I also introduced the "standard fare" of demographic variables: gender, age, race, ethnicity, education, political ideology, and household size. As census tract locations were available for the CCAMS respondents, I introduced census tract data from the American Community Survey (US Census Bureau, 2015) specifically: population density, educational attainment, and median income levels for respondent census tracts. ${ }^{28}$ Thus, with census tract data I was able to test for "neighborhood effects". ${ }^{29}$

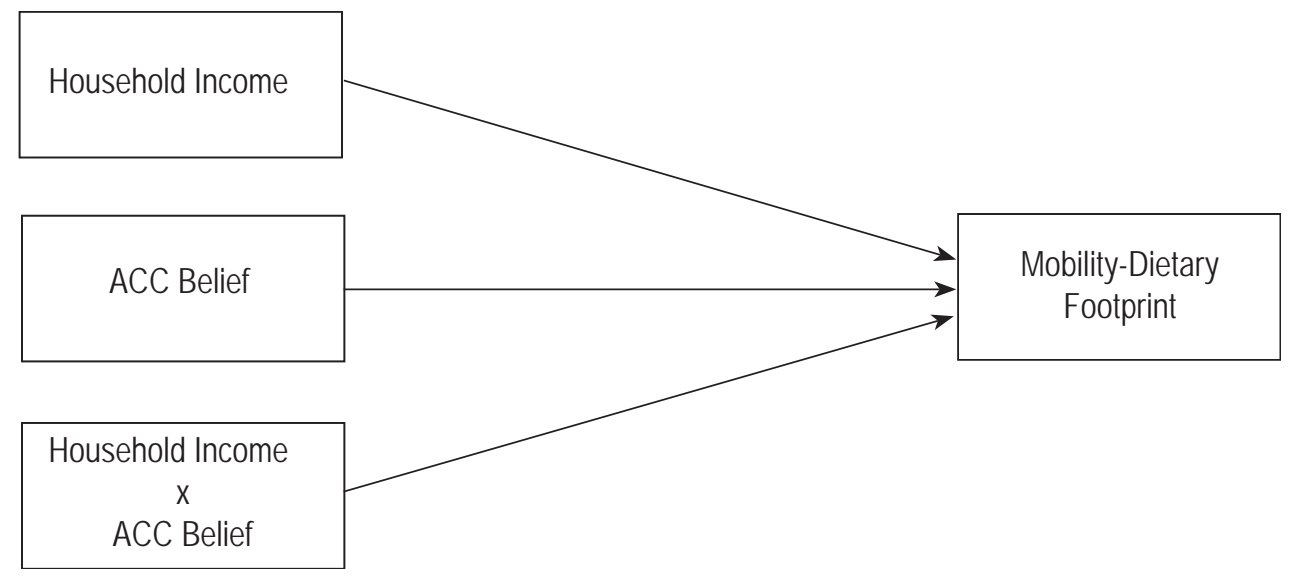

Source: Author's adaption from Baron and Kenny (1986).

Figure 2. Anthropogenic climate change belief moderating income-footprint path model

25 The signifiers ACC belief and CCAMS segmentation are used synonymously.

26 The terms household income and income are used synonymously, and always mean household income.

27 Moderation as defined by Baron and Kenny (1986) includes a test for interaction effects as seen in Figure 2: household income multiplied by ACC belief.

28 The ACS years 2006-2010 consist of a five-year estimate of census data and are considered the most appropriate for the 2008 CCAMS dataset.

29 The CCAMS also had a dichotomous metropolitan statistical area (MSA) measure - MSA / non-MSA - and this measure was also utilized in my analyses. 


\section{FINDINGS}

These findings were derived from four different ordinary least squares regression analyses, in which I tested the effects of ACC belief on the income-carbon relationship. The different analyses consisted of a combined total and three dimensions of that total: (1) the individual motor vehicle carbon footprint, (2) the air travel carbon footprint, (3) the dietary footprint, and (4) a combined total mobility and dietary carbon footprint. ${ }^{30}$ Each of these analyses was conducted on the same set of independent variables. The total mobility and dietary footprint is the summation of the two mobility footprints - vehicle and air - and the dietary footprint.

Descriptive statistics detailing the summations of the total mobility-dietary footprint - all sample respondent footprints $(\mathrm{N}=2107)$ added together - can be seen in Table 1 . Approximately $56 \%$ of this sum total is due to motor vehicle use, $24 \%$ to dietary habits, and $13 \%$ to air travel - see Figure 3. Though all sample respondents (100\%) are represented in the dietary footprint, only $88 \%(\mathrm{~N}=1859)$ and $37 \%(\mathrm{~N}=784)$ of respondents contribute to vehicle and air travel footprints, respectively. In other words, about $12 \%$ of the sample did not report motor vehicle use and $63 \%$ did not usually fly each year. ${ }^{31}$ Also, in Table 1, dietary GHGEs appear to be the most normal with mean, median, and mode values relatively close to each other; this is not the case for vehicle or flight GHGEs.

Table 1. Descriptive statistics of total carbon emissions.

\begin{tabular}{|c|c|c|c|c|}
\hline & 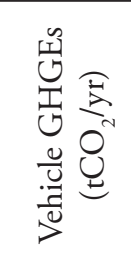 & 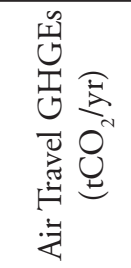 & 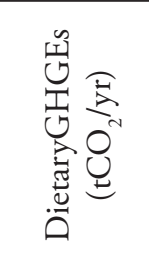 & 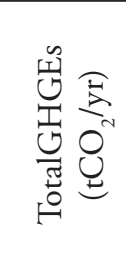 \\
\hline Mean & 6.312 & 2.218 & 2.695 & 11.224 \\
\hline Median & 3.512 & 0.00 & 2.674 & 7.452 \\
\hline Mode & 0.00 & 0.00 & 2.188 & 2.431 \\
\hline Sum & 13296.5 & 4671.7 & 5676.9 & 23645.1 \\
\hline Totals & $\begin{array}{c}56.2 \% \\
\mathrm{~N}=1859\end{array}$ & $\begin{array}{c}19.8 \% \\
N=784\end{array}$ & $\begin{array}{c}24.0 \% \\
\mathrm{~N}=2107\end{array}$ & $\begin{array}{l}100.0 \% \\
\mathrm{~N}=2107\end{array}$ \\
\hline Representation & $(88.2 \%)$ & $(37.2 \%)$ & $(100.0 \%)$ & \\
\hline
\end{tabular}

30 These dependent variables have units of measure in tons of $\mathrm{CO}_{2}$ over a one year period of time $\left(\mathrm{tCO}_{2} /\right.$ yr).

31 Note: the median value for air travel is zero. 


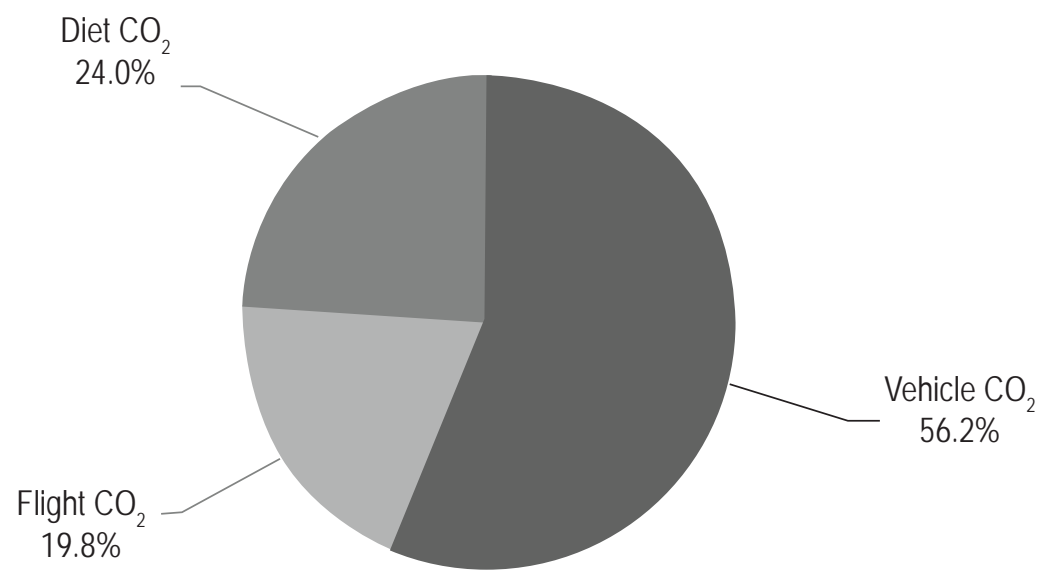

Figure 3. Composition of total mobility-dietary footprint.

\subsection{Stratified Emissions and the Income-Carbon Relationship}

Before detailing the multi-variate regression analyses, I review a number of bivariate figures which visually illustrate the stratification of the mobility-dietary footprint. Figure 4 depicts the sum totals of respondent GHGEs by population quintiles.

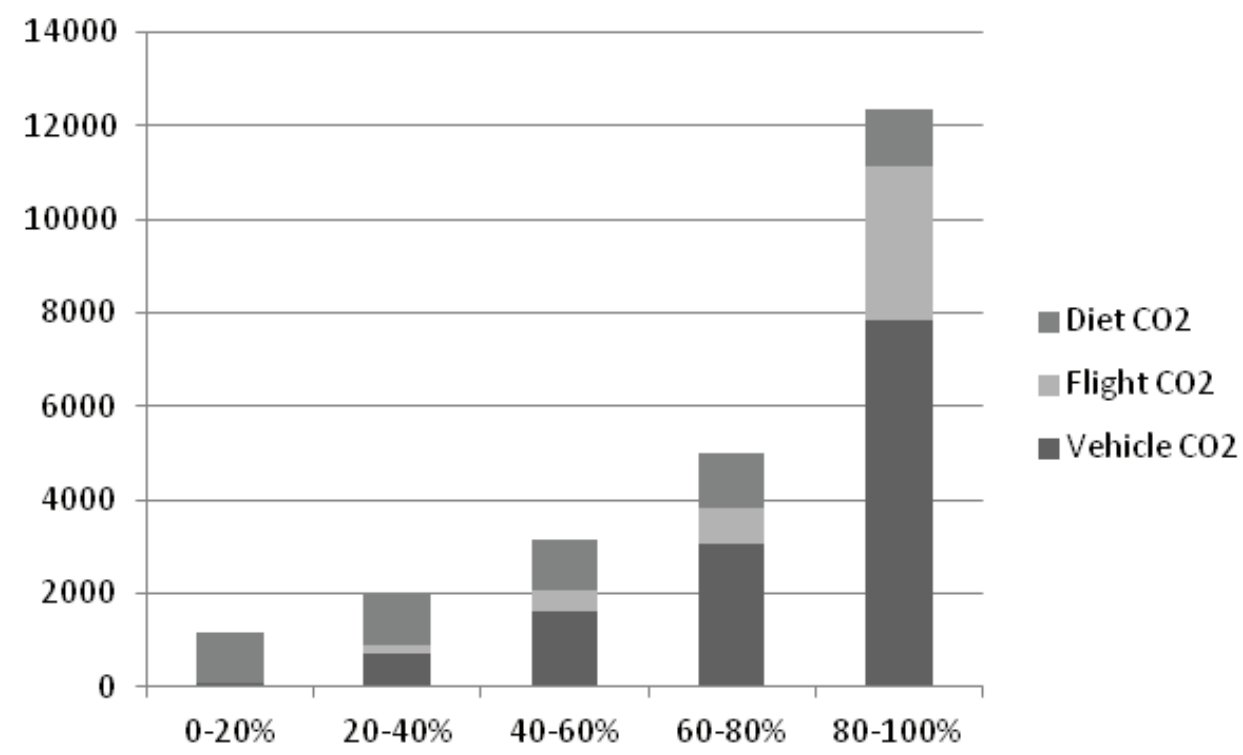

Figure 4. Carbon emissions by population quintiles. 


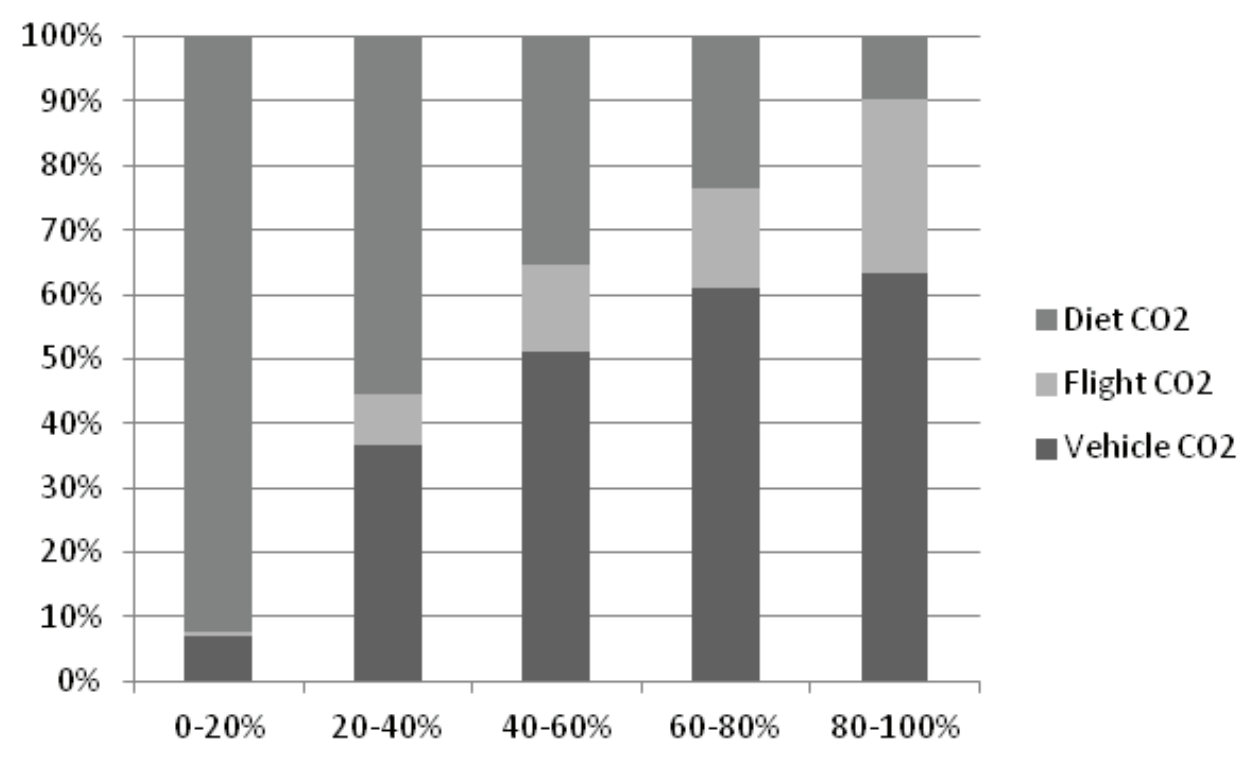

Figure 5. Carbon quintiles - relative proportions.

When moving from left to right, from the lowest emitter quintile group to the highest, a near exponential increase can be seen.

Similar to other studies (Chancel, 2014; Ummel, 2014), Figure 4 illustrates the level of emissions inequality: the top $20 \%$ of the sample emits more mobility-dietary carbon than the combined total of the bottom $80 \%$. The separate footprints which comprise the total carbon footprint can also be observed. Though dietary GHGEs remain near constant, there are - when moving left to right - near exponential increases in flight and vehicle footprint. In the lowest quintile, dietary carbon dominates emissions, while in the top quintile, it occupies a smaller fraction. Figure 5 depicts the very same data but as relative quintile proportions. Again, stark variances across the quintiles can be seen.

\subsection{Linear Regression Analyses}

Table 2 below displays the standardized models of the four regression analyses. ${ }^{32}$ Along the left side of Table 2 are the independent variables: demographics, political ideology, neighborhood effects, household income, and ACC belief - I dichotomized ACC belief

\footnotetext{
32 Prior to the dichotomization of the CCAMS belief variable into Alarmed and Non-Alarmed respondents, I ran two analyses which examined a reduced catchment of respondent attitudes: (i) the degree of certainty of one's global warming beliefs, (ii) the affirmation that it is human caused, and (iii) a broader catchment of attitudes - the individual segments of the CCAMS belief construct. Aside from some air travel, I found no association between belief and emissions from these early analyses and this finding informed my decision to dichotomize the CCAMS belief variable which was an integral factor to the construction of Table 2.
} 
into Alarmed and Non-Alarmed respondents. ${ }^{33}$ The bottom rows contain values for the adjusted $\mathrm{R}^{2}, \mathrm{~F}$ ratio, and number of observations. Column 1 displays the final regression output for vehicle carbon footprint per year $\left(\mathrm{tCO}_{2} / \mathrm{yr}\right)$; column 2, the dietary regression; column 3, the flight footprint; and column 4 the total mobility-dietary footprint. The dietary footprint model has the greatest predictive capacity with an $\mathrm{R}^{2}$ value of .813 and an $\mathrm{F}$ ratio of $416.424(\mathrm{p}<.01)$; the most powerful predictors are gender and age with significant negative correlations for female at $\mathrm{b}=-.798(\mathrm{p}<.01)$ and age at $\mathrm{b}=-.350$ $(\mathrm{p}<.01){ }^{34}$ The total mobility-dietary footprint is the next model in terms of explanatory capacity with an $\mathrm{R}^{2}$ of .119 and an F ratio of 13.903 (p<.01). The strength of this model may be a partial "carry over" of the dietary footprint - with a significant negative correlation for female at $b=-.106(p<.01)$; however, household income is the greatest predictor in this model with a significant positive correlation at $b=.320(\mathrm{p}<.01)$. Household size also has notable predictive capacity in this model with a significant negative correlation at $b=-.128(\mathrm{p}<.01)$.

When looking across the rows: age, household size, household income, the Income* Alarmed interactions are consistently significant. Age tends toward a significant negative correlation suggesting that people are emitting less carbon as they get older. Household size is more mixed, with a significant positive correlation for dietary footprint $(b=.045$; $\mathrm{p}<.01)$, but a significant negative correlation for vehicle footprint $(\mathrm{b}=-.112 ; \mathrm{p}<.01)$ and total footprint $(\mathrm{b}=-.128 ; \mathrm{p}<.01)$. These correlations suggest that individuals who live in larger households eat more of a meat-based diet, but they also have more passengers in their cars (reducing one's vehicle footprint) and fly less.

Except for dietary footprint, household income is a consistently significant positive predictor across all the regression analyses. ${ }^{35}$ It is most highly correlated with the total mobility-dietary footprint at $\mathrm{b}=.320$ ( $\mathrm{p}<.01)$. Dietary footprint aside, the Income ${ }^{*}$ Alarmed interaction in the climate change belief category is also a consistent, significantly negative factor in these models, with its strongest predictive capacity in the total footprint at $\mathrm{b}=-.161$ ( $\mathrm{p}<.01$ ). For those who are more highly educated (bachelor's degree and above), there are significant positive correlations for flight footprint and total footprint. Also, in the political ideology category, those who identify as liberal have significant negative correlations for dietary footprint but significant positive correlations for flight foot-

33 Besides including respondents who are more female, educated, liberal, and from more highly educated census tracts - the Alarmed demographic is not that different from the Non-Alarmed. For more detail, see Table 3 of the Appendix.

34 The sheer explanatory power of this model - nearly implausible - must be attributed to the calculation of the dietary footprint which was heavily based on respondent age and gender (see footnote 24).

35 The CCAMS household income is a variable with nineteen intervals: (1) Less than $\$ 5,000$; (2) $\$ 5,000$ to $\$ 7,499$; (3) $\$ 7,500$ to $\$ 9,999$; (4) $\$ 10,000$ to $\$ 12,499$; (5) $\$ 12,500$ to $\$ 14,999$; (6) $\$ 15,000$ to $\$ 19,999$; (7) $\$ 20,000$ to $\$ 24,999$; (8) $\$ 25,000$ to $\$ 29,999$; (9) $\$ 30,000$ to $\$ 34,999$; (10) $\$ 35,000$ to $\$ 39,999$; (11) $\$ 40,000$ to $\$ 49,999$; (12) $\$ 50,000$ to $\$ 59,999$; (13) $\$ 60,000$ to $\$ 74,999$; (14) $\$ 75,000$ to $\$ 84,999$; (15) $\$ 85,000$ to $\$ 99,999$; (16) $\$ 100,000$ to $\$ 124,999$; (17) $\$ 125,000$ to $\$ 149,999$; (18) $\$ 150,000$ to $\$ 174,999$; (19) $\$ 175,000$ or more. 
print; perhaps these correlations cancel each other out as they are not seen in the total footprint. There are also significant positive correlations between those who identify as somewhat conservative and the vehicle footprint $(\mathrm{b}=.060 ; \mathrm{p}<.05)$ and the total footprint $(b=.055 ; \mathrm{p}<.05)$. Finally, there are significant negative correlations between census tract population density and the vehicle footprint $(b=-.075 ; \mathrm{p}<.01)$ and the total footprint $(b=-.051 ; p<.05)$. I will discuss these findings in more depth below.

Figure 6 below was constructed with values from the total mobility-dietary footprint and illustrates the interaction of income and climate change beliefs. ${ }^{36}$ The vertical axis represents tons of $\mathrm{CO}_{2}$ per year and the horizontal axis is the CCAMS household income intervals. ${ }^{37}$ When compared to the slope of the Alarmed (gray line), it can be seen that with respect to income the total footprint of the Non-Alarmed (black line) rises more sharply. Also, around income interval 6 - household income of $\$ 20,000 /$ year, there is something of an income tipping point where the effect of ACC belief (being Alarmed) begins to have a greater impact on respondent carbon footprint. Figure 6, then, illustrates that the greatest effect of being Alarmed occurs in the highest income brackets, which is also where carbon emissions are the largest and where there is both a greater need and capacity for emission reductions.

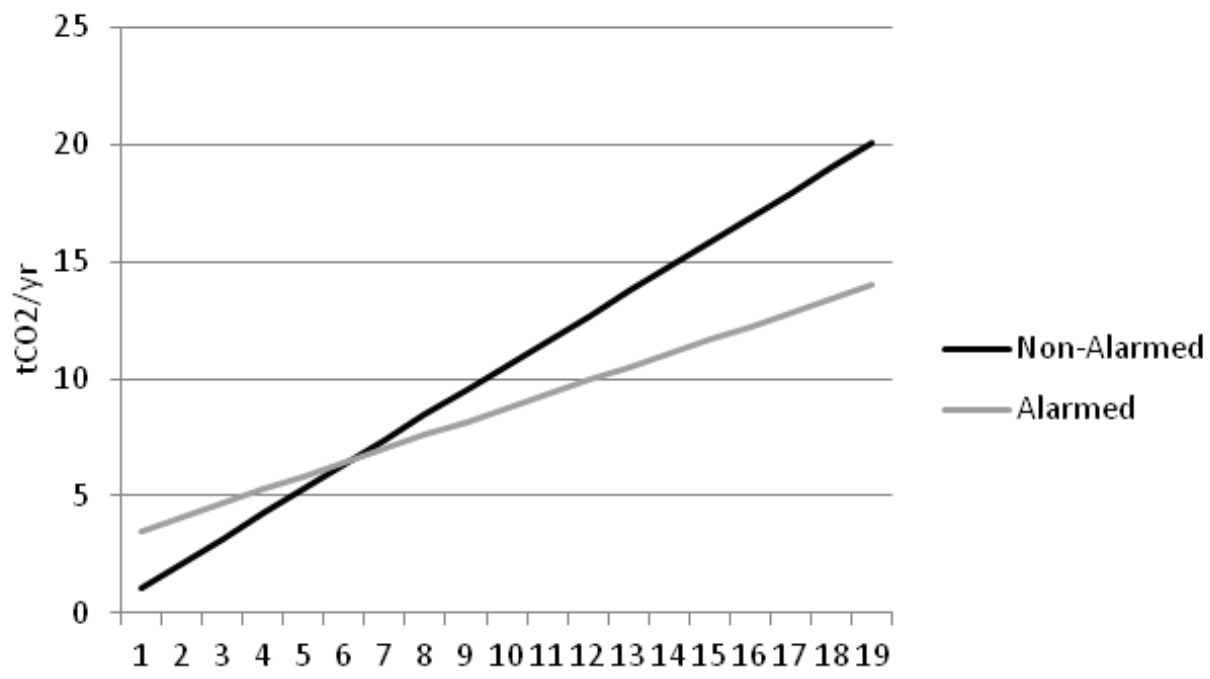

Household Income Intervals

Figure 6. Interaction of household income and climate change belief on total mobility-dietary footprint 
Table 2. The primary carbon models regressed on demographics, political ideology, neighborhood effects, household income, and climate change beliefs interaction.

\begin{tabular}{|c|c|c|c|c|}
\hline & 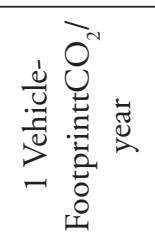 & 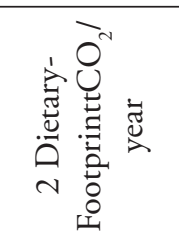 & 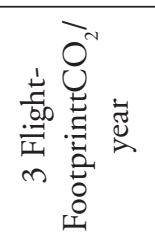 & 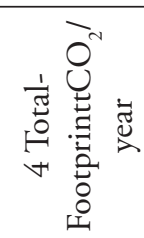 \\
\hline (Constant) & $-* * *$ & $-* * *$ &.$^{* *}$ & $-* * *$ \\
\hline Age & $-0.050^{* *}$ & $-0.350^{* * *}$ & $-0.047^{*}$ & $-0.080^{* * *}$ \\
\hline Male &.- & .- &.- & .-- \\
\hline Female & $-0.103^{* * *}$ & $-0.798^{* * *}$ & 0.004 & $-0.106^{* * *}$ \\
\hline High school or less & .-- & .- &.- & .-- \\
\hline Some college/Assoc. & 0.010 & 0.006 & -0.027 & -0.008 \\
\hline Bachelor's degree & 0.019 & 0.016 & 0.042 & $0.041^{*}$ \\
\hline Master's or more & -0.001 & 0.000 & $0.082^{* * *}$ & $0.049^{* *}$ \\
\hline White &.-- &.- &.- &.- \\
\hline Black & 0.027 & 0.005 & $0.056^{* *}$ & $0.056^{* *}$ \\
\hline Other (Non-Hispanic) & -0.034 & -0.009 & $0.065^{* * *}$ & 0.013 \\
\hline Hispanic & 0.029 & $-0.039^{* * *}$ & 0.037 & $0.044^{* *}$ \\
\hline Two or more races & 0.020 & 0.002 & 0.002 & 0.017 \\
\hline Household size & $-0.112^{* * *}$ & $0.045^{* * *}$ & $-0.066^{* * *}$ & $-0.128^{* * *}$ \\
\hline Moderate & .- & .-- &.- & .- \\
\hline Very liberal & -0.025 & $-0.039^{* * *}$ & $0.063^{* * *}$ & 0.017 \\
\hline Somewhat liberal & -0.026 & $-0.022^{* *}$ & $0.066^{* * *}$ & 0.019 \\
\hline Somewhat conservative & $0.060^{* *}$ & 0.013 & 0.011 & $0.055^{* *}$ \\
\hline Very conservative & 0.007 & 0.005 & -0.032 & -0.014 \\
\hline Item non-response & -0.024 & 0.000 & -0.005 & -0.022 \\
\hline CT Median income & 0.002 & 0.004 & -0.001 & 0.001 \\
\hline CT \% BA degree & $-0.070^{* *}$ & 0.001 & 0.016 & -0.046 \\
\hline MSA status & 0.016 & 0.000 & 0.027 & 0.029 \\
\hline CT Pop. density & $-0.075^{* * *}$ & 0.015 & 0.013 & $-0.051^{* *}$ \\
\hline Household income & $0.233^{* * *}$ & $-0.020^{*}$ & $0.222^{* * *}$ & $0.320^{* * *}$ \\
\hline Non-Alarmed & .-- & .- & .-- & .-- \\
\hline Alarmed & 0.045 & $-0.062^{* * *}$ & 0.078 & 0.081 \\
\hline Income * Alarmed & $-0.099 *$ & 0.002 & $-0.134^{* *}$ & $-0.161^{* * *}$ \\
\hline Adjusted R2 & 0.073 & 0.813 & 0.075 & 0.119 \\
\hline F value & $8.586^{* * *}$ & $416.424^{* * *}$ & $8.725^{* * *}$ & $13.903^{* * *}$ \\
\hline Number of Observations & 2107 & 2107 & 2107 & 2107 \\
\hline
\end{tabular}

Source: Climate Change in the American Mind Survey (2008); US Census Bureau (2015); Abbreviations: $C T=$ Census Tract; $M S A=$ Metropolitan Statistical Area; .-- indicates reference category, * $p<.10,{ }^{* *} p<.05,{ }^{* * *} p<.01$ 


\section{DISCUSSION AND CONCLUSION}

In this discussion I focus on the object of this research: the moderating capacities of ACC belief on the income-carbon relationship. I also concentrate more on the total mobility-dietary carbon footprint, rather than the individual regression models. Additionally, it is perhaps good to recall that this data is from 2008 and the scope of this research only includes reported mobility-dietary behaviors and their related GHGEs - in other words, there are other carbon emissive behaviors related to human behavior. Starting with the demographic variables, there are significant negative correlations with age. This dynamic may be due to "life roles" attributable to age, i.e. life course and / or workforce characteristics, or generational age cohort characteristics. It may well be due to people becoming more settled and comparatively consuming, flying and driving less as they get older. Setting air travel aside, the significant negative correlations for female may be related to the traditional - though changing - gender separation of labor, with men out of the house and driving more than women. Interestingly, this "travel-for-work dynamic" was not evident with the flight footprint. ${ }^{38}$

Educational attainment offers something of a mixed effect. Higher education - bachelor's degree and above - positively contributed, on average, to air travel carbon emissions, and this was reflected in the total footprint. This may have to do with the demands, apart from income, of one's occupation. These effects of education, independent of income, may be due to cultural characteristics which align well with Bourdieu's ([1979]1984) insights into education and class culture - where cultural drivers to maintain social status and symbolic capital may outpace economic drivers.

When considering the total mobility-dietary footprint, there are significant positive correlations to be seen with Black and Hispanic (compared to White). There is perhaps a cultural attribute beneath these correlations; the Black correlation appears to be a direct carry-over from the flight footprint: Are Blacks flying relatively more for some reason? Might this be a consequence of migration and respondent visits to countries of origin? This requires further research. The positive Hispanic correlation, however, seems to result from a sum of parts, as it is not present in the other models - though it is present, negatively, in dietary carbon. The race / ethnicity category of other (non-Hispanic) had a significant positive correlation for air travel footprint. However, this correlation did not carry over to the total mobility-dietary footprint.

When considering household size, it perhaps helps to consider how more people in one's home - both through social norms and sheer consumptive needs - affects behavior. Firstly, there is probably an association between household size and the number of passengers usually in someone's vehicle - number of passengers was a denominator in the respondent vehicle footprint calculations. Accordingly, there are significant negative correlations with vehicle and total carbon footprint. There is also, though, a significant negative correlation with flight footprint: might flying be too expensive for large

38 Again, some of these age and gender correlations may be attributable to the dietary footprint calculation. 
families or do they have trouble "getting away"? Concerning dietary GHGEs, there is a significant positive correlation with household size. Perhaps it is difficult for people from larger homes to moderate their dietary choices (i.e. "go vegetarian"); however, this requires further research.

When considering political ideology in the total mobility-dietary footprint, there is a significant positive correlation for only one political response: somewhat conservative. This particular correlation appears to be attributable to, and a "carry-over" from, the vehicle footprint. Interestingly, somewhat conservative is the second largest ideological population $(23 \%)$ and it may be representative, as far as car use, of a commuter culture. There is also a significant negative correlation between vehicle GHGEs and population density, which seems to align with a "commuter culture" frame and Bourdieu's ([1979]1984, [1993]1999) views on lifestyles and site effects. However, this requires more research. Concerning those with more liberal ideological tendencies and their significant negative correlations with dietary footprint and, conversely, significant positive correlations with flying: perhaps these contrary tendencies resolve themselves as there are no significant correlations related to liberal responses in the total mobility-dietary footprint.

Neighborhood effects were primarily found relative to the motor vehicle. Concerning the significant negative correlation between census tract population density and both vehicle and total GHGEs (i.e. the more dense a census tract, the less car usage), there is evidence in the literature for this relationship: those in more urban areas "share" more resources, have greater access to public transportation, and drive less (Dargay, 2002; Heinonen et al., 2013; Jones and Kammen, 2014) ${ }^{39}$ There is also a significant negative correlation between census tract percentage of bachelor degrees (or above) and vehicle footprint; apparently census tracts with higher levels of education are producing relatively lower driving impacts. This particular relationship, though, did not carry over into the total mobility-dietary footprint.

\subsection{Household Income and Climate Change Belief}

Confirming the literature, household income - dietary carbon aside - had the largest significant impact of any independent variable. This finding reaffirms the established "income-carbon" relationship, the "inequalities" of carbon emissions, and lifestyle lockin..$^{40}$ When examining the total footprint for a finding concerning the main question animating this research: Does ACC belief moderate the income-carbon relationship?, the finding is mixed and depends on what is meant by "belief". For strong "believers" like the CCAMS composite construct Alarmed, the answer is yes: ACC belief does moderate the income-carbon relationship. However, for those who are not strong believers, like the CCAMS Concerned or Cautious, the answer is no: this belief is not strong enough.

39 However, Heinonen et al. (2013) also argue that some overlooked behaviors may offset the "urban advantage" of proximity.

40 Rather than thinking of income as a medium for buying and disposing of products, energy and emissions, it could be thought of as a proxy for a set of normative, socially positioned behaviors - an income lifestyle, a class culture. 
Thus, since the strongest ACC believer - the Alarmed - has demonstrated the potential to bridge the A-B gap; I reject my original null hypothesis.

This is not the first time scholars report that strong attitudes can overcome certain contexts (Guagnano et al., 1995) and with this finding I argue against the proponents of an A-B gap (Blake, 1999; Csutora, 2012; Gatersleben et al., 2002; Hoggett, 2013; Kollmuss and Agyeman, 2002; Whitmarsh et al., 2011; Wilson et al., 2013). Additionally, I align myself with scholars who argue that, essentially, the A-B gap is a measurement problem (Guber, 2013; Lertzman, 2013; Newhouse, 1990). In other words, there is no gap when a larger catchment of human concerns - like the multifaceted CCAMS belief construct - is considered in aggregate. ${ }^{41}$

In conclusion, I must reiterate that the income-carbon moderating capacity of the strong ACC attitude is slight and that - dietary emissions aside - income remains the most dominant predictive variable of GHGEs. This means that though an A-B gap may have been bridged, it may not make a great environmental difference. Thus, in light of this finding - that regardless of climate change belief those with the lowest incomes generally emit the lowest amounts of $\mathrm{CO}_{2}$, I recommend policy tools - such as greater taxes and limits on both income and carbon emissions - that more directly constrain personal carbon emissive behaviors. Similar to the arguments of others, it appears that the most effective place to create environmentally significant behavioral change is at the structural, governmental, and institutional level (IPCC, 2014a; Princen et al., 2002; Szasz, 2011). However, I do not suggest this because I think culture and behavior are not powerful areas for creating change, but because I think it is difficult to intentionally generate change in these areas.

\section{REFERENCES}

Balderjahn, I. (1988). Personality Variables and Environmental Attitudes as Predictors of Ecologically Responsible Consumption Patterns. Journal of Business Research, 17(1): 51-56.

Baron, R. M. and Kenny, D. A. (1986). The Moderator-Mediator Variable Distinction in Social Psychological Research: Conceptual, Strategic, and Statistical Considerations. Journal of Personality and Social Psychology, 51(6): 1173-1182.

Bin, S. and Dowlatabadi, H. (2005). Consumer Lifestyle Approach to US Energy Use and the Related CO2 Emissions. Energy Policy, 33(2): 197-208.

Blake, J. (1999). Overcoming the 'Value-Action Gap' in Environmental Policy: Tensions between National Policy and Local Experience. Local Environment, 4(3): 257278.

Bourdieu, P. ([1979]1984). Distinction: A Social Critique of the Judgement of Taste. Cambridge: Harvard University Press.

41 There may be a gap between environmental attitudes and environmental behaviors, but human beings are not unidimensional. 
Bourdieu, P. ([1993]1999). Site Effects. In: Bourdieu, P. et al. (eds.), The Weight of the World: Social Suffering in Contemporary Society (pp. 123-129). Stanford: Stanford University Press.

Brulle, R. J. (2010.) From Environmental Campaigns to Advancing the Public Dialog: Environmental Communication for Civic Engagement. Environmental Communication: A Journal of Nature and Culture, 4(1): 82-98.

Caldeira, K. and Davis, S. J. (2011). Accounting for Carbon Dioxide Emissions: A Matter of Time. Proceedings of the National Academy of Sciences, 108(21): 8533-8534.

Capstick, S., Whitmarsh, L., Poortinga, W., Pidgeon, N., Upham, P. (2015). International Trends in Public Perceptions of Climate Change over the Past Quarter Century. Wiley Interdisciplinary Reviews: Climate Change, 6(1): 35-61.

Carfagna, L. B., Dubois, E. A., Fitzmaurice, C., Ouimette, M. Y., Schor, J. B., Willis, M., Laidley, T. (2014). An Emerging Eco-Habitus: The Reconfiguration of High Cultural Capital Practices among Ethical Consumers. Journal of Consumer Culture, 14(2): 158-178.

Chancel, L. (2014). Are Younger Generations Higher Carbon Emitters than Their Elders? Inequalities, Generations and $\mathrm{CO} 2$ Emissions in France and in the USA. Ecological Economics, 100: 195-207.

Chichilnisky, G. and Heal, G. (1994). Who Should Abate Carbon Emissions? An International Viewpoint. Economics Letters, 44(4): 443-449.

Clements, J. M., McCright, A. M., Dietz, T., Marquart-Pyatt, S. T. (2015). A Behavioural Measure of Environmental Decision-Making for Social Surveys. Environmental Sociology, 1(1): 27-37.

Csutora, M. (2012). One More Awareness Gap? The Behaviour-Impact Gap Problem. Journal of Consumer Policy, 35(1): 145-163.

Dargay, J. M. (2002). Determinants of Car Ownership in Rural and Urban Areas: A Pseudo-Panel Analysis. Transportation Research Part E: Logistics and Transportation Review, 38(5): 351-366.

Davis, S. J. and Caldeira, K. (2010). Consumption-Based Accounting of CO2 Emissions. Proceedings of the National Academy of Sciences of the United States of America, 107(12): 5687-5692.

Dey, C. (2010). The 2008-09 Ecological Footprint of the Population of the Australian Capital Territory. Sydney: The University of Sydney.

Diamantopoulos, A., Schlegelmilch, B. B., Sinkovics, R. R., Bohlen, G. M. (2003). Can Socio-Demographics Still Play a Role in Profiling Green Consumers? A Review of the Evidence and an Empirical Investigation. Journal of Business Research, 56(6): 465-480.

Dietz, T., Dan, A., Shwom, R. (2007). Support for Climate Change Policy: Social Psychological and Social Structural Influences. Rural Sociology, 72(2): 185-214.

Dietz, T., Gardner, G. T., Gilligan, J., Stern, P. C., Vandenbergh, M. P. (2009). Household Actions can Provide a Behavioral Wedge to Rapidly Reduce US Carbon Emissions. Proceedings of the National Academy of Sciences, 106(44): 18452-18456. 
Dolenec, D., Domazet, M., Ančić, B. (2014.) Why Power is Not a Peripheral Concern: Exploring the Relationship between Inequality and Sustainability. In: Domazet, M. and Marinović Jerolimov, D. (eds.), Sustainability Perspectives from the European Semi-periphery (pp. 173-194). Zagreb: Institute for Social Research.

Domazet, M., Ančić, B., Brajdić Vuković, M. (2014). Prosperity and Environmental Sacrifice. In: Domazet, M. and Marinović Jerolimov, D. (eds.), Sustainability Perspectives from the European Semi-periphery (pp. 145-172). Zagreb: Institute for Social Research.

Douglas, M., Gasper, D., Ney, S., Thompson, M. (1998). Human Needs and Wants. In: Rayner, S. and Malone, E. L. (eds.), Human Choice and Climate Change. Volume 1: The Societal Frame Work (pp. 195-260). Columbus, OH: Battelle.

Druckman, A. and Jackson, T. (2008). Household Energy Consumption in the UK: A Highly Geographically and Socio-Economically Disaggregated Model. Energy Policy, 36(8): 3177-3192.

Druckman, A. and Jackson, T. (2009). The Carbon Footprint of UK Households 19902004: A Socio-Economically Disaggregated, Quasi-Multi-Regional Input-Output Model. Ecological Economics, 68(7): 2066-2077.

Dunlap, R. E. and McCright, A.M. (2008). A Widening Gap: Republican and Democratic Views on Climate Change. Environment: Science and Policy for Sustainable Development, 50(5): 26-35.

Dunlap, R. E. and York, R. (2008). The Globalization of Environmental Concern and the Limits of the Postmaterialist Values Explanation: Evidence from Four Multinational Surveys. The Sociological Quarterly, 49(3): 529-563.

Ehrlich, P. R. and Holdren, J. P. (1971). Impact of Population Growth. Science, 171(3977): 1212-1217.

Ellen, P. S., Wiener, J. L., Cobb-Walgren, C. (1991). The Role of Perceived Consumer Effectiveness in Motivating Environmentally Conscious Behaviors. Journal of Public Policy \& Marketing, 10(2): 102-117.

Fahmy, E., Thumim, J., White, V. (2011). The Distribution of UK Household CO2 Emissions: Interim Report. JRF Programme Paper: Climate Change and Social Justice. University of Bristol and Centre for Sustainable Energy.

Fransson, N. and Gärling. T. (1999). Environmental Concern: Conceptual Definitions, Measurement Methods, and Research Findings. Journal of Environmental Psycho$\log y, 19(4): 369-382$.

Franzen, A. and Meyer, R. (2010). Environmental Attitudes in Cross-National Perspective: A Multilevel Analysis of the ISSP 1993 and 2000. European Sociological Review, 26(2): 219-234.

Franzen, A., and Vogl, D. (2013). Two decades of measuring environmental attitudes: A comparative analysis of 33 countries. Global Environmental Change, 23(5): 1001-1008.

Gärling, T., Bamberg, S., Friman, M., Fujii, S., Richter, J. (2009). Implementation of Soft Transport Policy Measures to Reduce Private Car Use in Urban Areas. Panels of the Energy Efficiency and Behaviour Conference 2009. European Council for an 
Energy Efficient Economy. URL: http://www.eceee.org/library/conference_proceedings/EE_and_Behaviour/2009/Panel_5/5.501 (August 30, 2016).

Gatersleben, B., Steg, L., Vlek, C. (2002). Measurement and Determinants of Environmentally Significant Consumer Behavior. Environment and Behavior, 34(3): 335-362.

Griskevicius, V., Cantú, S. M., van Vugt, M. (2012). The Evolutionary Bases for Sustainable Behavior: Implications for Marketing, Policy, and Social Entrepreneurship. Journal of Public Policy \& Marketing, 31(1): 115-128.

Guagnano, G. A., Stern, P. C., Dietz, T. (1995). Influences on Attitude-Behavior Relationships: A Natural Experiment with Curbside Recycling. Environment and Behavior, 27(5): 699-718.

Guber, D. L. (2013). A Cooling Climate for Change? Party Polarization and the Politics of Global Warming. American Behavioral Scientist, 57(1): 93-115.

Haustein, S. and Hunecke, M. (2007). Reduced Use of Environmentally Friendly Modes of Transportation Caused by Perceived Mobility Necessities: An Extension of the Theory of Planned Behavior. Journal of Applied Social Psychology, 37(8): 1856-1883.

Heinonen, J., Jalas, M., Juntunen, J. K., Ala-Mantila, S., Junnila, S. (2013). Situated lifestyles: I. How Lifestyles Change along with the Level of Urbanization and What the Greenhouse Gas Implications Are - A Study of Finland. Environmental Research Letters, 8(2): 025003.

Hertwich, E. G. and. Peters, G. P. (2009). Carbon Footprint of Nations: A Global, Trade-Linked Analysis. Environmental Science \& Technolo gy, 43(16): 6414-6420.

Hines, J. M., Hungerford, H. R. Tomera, A. N. (1987). Analysis and Synthesis of Research on Responsible Environmental Behavior: A Meta-Analysis. The Journal of Environmental Education, 18(2): 1-8.

Hoggett, P. (2013). Climate Change in a Perverse Culture. In: Weintrobe, S. (ed.), Engaging with Climate Change: Psychoanalytic and Interdisciplinary Perspectives (pp. 56-71). New York: Routledge.

Howe, P. D., Mildenberger, M., Marlon, J. R., Leiserowitz, A. (2015). Geographic Variation in Opinions on Climate Change at State and Local Scales in the USA. Nature Climate Change, 5(6): 596-603.

Inglehart, R. (1990). Culture Shift in Advanced Industrial Society. Princeton: Princeton University Press.

IPCC. (2014a). Summary for Policymakers. Climate Change 2014, Mitigation of Climate Change. Contribution of Working Group III to the Fifth Assessment Report of the Intergovernmental Panel on Climate Change. Cambridge: Cambridge University Press.

IPCC. (2014b). Technical Summary. Climate Change 2014, Mitigation of Climate Change. Contribution of Working Group III to the Fifth Assessment Report of the Intergovernmental Panel on Climate Change. Cambridge: Cambridge University Press.

Jackson, T. (2005). Motivating Sustainable Consumption: A Review of Evidence on Consumer Behaviour and Behavioural Change. A Report to the Sustainable Development Research Network. Guildford: Centre for Environmental Strategy, University of Surrey. 
Jones, C. and Kammen, D. M. (2014). Spatial Distribution of U.S. Household Carbon Footprints Reveals Suburbanization Undermines Greenhouse Gas Benefits of Urban Population Density. Environmental Science \& Technology, 48(2): 895-902.

Jones, C. M. and Kammen, D. M. (2011). Quantifying Carbon Footprint Reduction Opportunities for U.S. Households and Communities. Environmental Science \& Technology, 45(9): 4088-4095.

Jones, R. E. and Dunlap, R. E. (1992). The Social Bases of Environmental Concern: Have They Changed Over Time? Rural Sociology, 57(1): 28-47.

Kahan, D. M., Peters, E., Wittlin, M., Slovic, P., Ouellette, L. L., Braman, D., Mandel, G. (2012). The Polarizing Impact of Science Literacy and Numeracy on Perceived Climate Change Risks. Nature Climate Change, 2(10): 732-735.

Kaiser, F. G., Hübner, G., Bogner, F. X. (2005). Contrasting the Theory of Planned Behavior with the Value-Belief-Norm Model in Explaining Conservation Behavior. Journal of Applied Social Psychology, 35(10): 2150-2170.

Kassarjian, H. H. (1971). Incorporating Ecology into Marketing Strategy: The Case of Air Pollution. Journal of Marketing, 35(3): 61-65.

Kollmuss, A. and Agyeman, J. (2002). Mind the Gap: Why Do People Act Environmentally and What are the Barriers to Pro-Environmental Behavior? Environmental Education Research, 8(3): 239-260.

Kurz, T. (2002). The Psychology of Environmentally Sustainable Behavior: Fitting Together Pieces of the Puzzle. Analyses of Social Issues and Public Policy, 2(1): 257-278.

Laidley, T. M. (2013). The Influence of Social Class and Cultural Variables on Environmental Behaviors Municipal-Level Evidence from Massachusetts. Environment and Behavior, 45(2): 170-197.

LaPiere, R. T. (1934). Attitudes vs. Actions. Social Forces, 13(2): 230-237.

Leiserowitz, A. and Feinberg, G. (2005). American Risk Perceptions: Is Climate Change Dangerous? Risk analysis, 25(6): 1433-1442.

Leiserowitz, A., Maibach, E., Roser-Renouf, C. (2009). Global Warming's Six Americas 2009: An Audience Segmentation Analysis. Yale University and George Mason University. New Haven, CT: Yale Project on Climate Change Communication.

Leiserowitz, A., Maibach, E., Roser-Renouf, C., Feinberg, G., Rosenthal, S. (2014). Politics \& Global Warming, Spring 2014. Yale University and George Mason University. New Haven, CT: Yale Project on Climate Change Communication.

Leiserowitz, A., Maibach, E., Roser-Renouf, C., Hmielowski. J. D. (2011). Politics \& Global Warming: Democrats, Republicans, Independents, and the Tea Party. Yale University and George Mason University. New Haven, CT: Yale Project on Climate Change Communication.

Leiserowitz, A., Maibach, E., Roser-Renouf, C., Hmielowski. J. D. (2012). Global Warming's Six Americas in March 2012 and November 2011. Yale University and George Mason University. New Haven, CT: Yale Project on Climate Change Communication.

Lenzen, M. and Murray, S. A. (2001). A Modified Ecological Footprint Method and Its Application to Australia. Ecological Economics, 37(2): 229-255. 
Lertzman, R. (2013). The Myth of Apathy: Psychoanalytic Explorations of Environmental Subjectivity. In: Weintrobe, S. (ed.), Engaging with Climate Change: Psychoanalytic and Interdisciplinary Perspectives (pp. 117-133). New York: Routledge.

Linville, P. W. and Fischer, G. W. (1991). Preferences for Separating or Combining Events. Journal of Personality and Social Psychology, 60(1): 5-23.

Lynas, M. (2007). Carbon Counter: Calculate Your Carbon Footprint. London: HarperCollins.

Lyons, S., Pentecost, A., Tol, R. S. J. (2012). Socioeconomic Distribution of Emissions and Resource Use in Ireland. Journal of Environmental Management, 112: 186-198.

Maibach, E. W., Leiserowitz, A., Roser-Renouf, C., Mertz, C. K. (2011). Identifying Like-Minded Audiences for Global Warming Public Engagement Campaigns: An Audience Segmentation Analysis and Tool Development. PLoS ONE 6(3): 1-9.

Maibach, E. W., Roser-Renouf, C., Leiserowitz, A. (2008). Communication and Marketing as Climate Change-Intervention Assets: A Public Health Perspective. American Journal of Preventive Medicine, 35(5): 488-500.

Martiskainen, M. (2007). Affecting Consumer Behaviour on Energy Demand. Sussex Energy Group. SPRU - Science and Technology Policy Research. Brighton: University of Sussex.

McCright, A. M. (2009). The Social Bases of Climate Change Knowledge, Concern, and Policy Support in the U.S. General Public. Hofstra Law Review, 37(4/7): 1017-1047.

McKenzie-Mohr, D. (2011). Fostering Sustainable Behavior: An Introduction to Community-Based Social Marketing. Gabriola Island, Canada: New Society Publishers.

Melillo, J. M., Richmond, T., Yohe, G. W. (2014). Climate Change Impacts in the United States: The Third National Climate Assessment. U.S. Global Change Research Program. DOI: $10.7930 / \mathrm{J0Z31WJ2.}$

Munasinghe, M. (2010). Can Sustainable Consumers and Producers Save the Planet? Journal of Industrial Ecology, 14(1): 4-6.

Nagel, J., Dietz, T., Broadbent, J. (2010). Workshop on Sociological Perspectives on Global Climate Change. National Science Foundation.

Newhouse, N. (1990). Implications of Attitude and Behavior Research for Environmental Conservation. Journal of Environmental Education, 22(1): 26-32.

Newport, F. (2010). Americans' Global Warming Concerns Continue to Drop. Gallup. URL: http://people.uncw.edu/imperialm/UNCW/PLS_543/PLS_543_Handouts/ Gallop_Global_Warming_Opinion_3_11_10.pdf (May 11, 2014).

Nisbet, M. C. and Myers, T. (2007). The Polls - Trends: Twenty Years of Public Opinion about Global Warming. Public Opinion Quarterly, 71(3): 444-470.

Osbaldiston, R. and Schott, J. P. (2012). Environmental Sustainability and Behavioral Science Meta-Analysis of Proenvironmental Behavior Experiments. Environment and Behavior, 44(2): 257-299.

Padgett, J. P., Steinemann, A. C., Clarke, J. H., Vandenbergh, M. P. (2008). A Comparison of Carbon Calculators. Environmental Impact Assessment Review, 28(2-3): 106-115. 
Perkowiz, R., Speiser, M., Harp, G., Hodge, C., Krygsman, K. (2014). American Climate Values 2014: Psychographic and Demographic Insights. Washington, DC: Strategic Business Insights and ecoAmerica.

Peters, G. P., Minx, J. C., Weber, C. L., Edenhofer, O. (2011). Growth in Emission Transfers via International Trade from 1990 to 2008. Proceedings of the National Academy of Sciences of the United States of America, 108(21): 8903-8908.

Pew, Research Center. (2009). Economy, Jobs Trump All Other Policy Priorities In 2009. Washington, DC: Pew Research Center for the People and the Press. URL: http:// www.people-press.org/2009/01/22/economy-jobs-trump-all-other-policy-priorities-in-2009/ (May 11, 2014).

Princen, T., Maniates, M., Conca, K. (eds.) (2002). Confronting Consumption. Cambridge, MA: MIT Press.

Rayner, S. and Malone, E. L. (1998). Introduction: Why Study Human Choice and Climate Change? In: Rayner, S. and Malone, E. L. (eds.), Human Choice and Climate Change. Volume 1: The Societal Frame Work (pp. 13-42). Columbus, OH: Battelle.

Roberts, J. A. and Bacon, D. R. (1997). Exploring the Subtle Relationships between Environmental Concern and Ecologically Conscious Consumer Behavior. Journal of Business Research, 40(1): 79-89.

Saad, L. (2009). Increased Number Think Global Warming is 'Exaggerated.' Gallup. URL: http://news.heartland.org/sites/all/modules/custom/heartland_migration/ files/pdfs/24880.pdf (May 11, 2014).

Sanne, C. (2002). Willing Consumers - or Locked-In? Policies for a Sustainable Consumption. Ecological Economics, 42(1-2): 273-287.

Schipper, L., Bartlett, S., Hawk, D., Vine, E. (1989). Linking life-Styles and Energy Use: A Matter of Time? Annual Review of Energy, 14(1): 273-320.

Schultz, P. W., Gouveia, V.V., Cameron, L. D., Tankha, G., Schmuck, P. (2005). Values and their Relationship to Environmental Concern and Conservation Behavior. Journal of Cross-Cultural Psychology, 36(4): 457-475.

Schuman, H. and Johnson, M. P. (1976). Attitudes and Behavior. Annual Review of Sociology, 2: 161-207.

Shove, E. (2003). Comfort, Cleanliness and Convenience: The Social Organization of Normality. New York: Berg.

Stern, P. C. (2000a). New Environmental Theories: Toward a Coherent Theory of Environmentally Significant Behavior. Journal of Social Issues, 56(3): 407-424.

Stern, P. C. (2000b). Toward a Coherent Theory of Environmentally Significant Behavior. Journal of Social Issues, 56(3): 407-424.

Szasz, A. (2011). Is Green Consumption Part of the Solution? In Dryzek, J. S., Norgaard, R. B., Schlosberg, D. (eds.), The Oxford Handbook of Climate Change and Society, (pp. 594-611). Oxford: Oxford University Press.

Thogersen, J. (2005). How May Consumer Policy Empower Consumers for Sustainable Lifestyles? Journal of Consumer Policy, 28(2): 143-177.

Tucker, L. R., Jr. (1978). The Environmentally Concerned Citizen: Some Correlates. Environment and Behavior, 10(3): 389-418. 
Ummel, K. (2014). Who Pollutes? A Household-Level Database of America's Greenhouse Gas Footprint. Working Paper 381. Washington, DC: Center for Global Development.

US Census Bureau. (2015). American Community Survey 5-Year Estimates - GeodatabaseFormat. TIGER / Line ${ }^{\bullet}$ with Selected Demographic and Economic Data. URL: http://www.census.gov/geo/maps-data/data/tiger-data.html (October 15, 2015).

USDA. (2010). Dietary Guidelines for Americans 2010. Washington, DC: U.S. Department of Agriculture.

USDA-ERS. (2014). Food Availability (Per Capita) Data System: Loss-Adjusted Food Availability. Washington, DC: U.S. Department of Agriculture - Economic Research Service. URL: http://www.ers.usda.gov/data-products/food-availability-(percapita)-data-system/.aspx\#26705 (July 3, 2015).

Verplanken, B. (2011). Old Habits and New Routes to Sustainable Behaviour. In: Whitmarsh, L., Lorenzoni, I., O'Neill, S. (eds.), Engaging the Public with Climate Change: Behaviour Change and Communication (pp. 17-30). London: Earthscan.

Weber, C. and Perrels, A. (2000). Modelling Lifestyle Effects on Energy Demand and Related Emissions. Energy Policy, 28(8): 549-566.

Whitmarsh, L. (2009). Behavioural Responses to Climate Change: Asymmetry of Intentions and Impacts. Journal of Environmental Psychology, 29(1): 13-23.

Whitmarsh, L., Seyfang, G., O’Neill, S. (2011). Public Engagement with Carbon and Climate Change: To What Extent is the Public 'Carbon Capable'? Global Environmental Change, 21(1): 56-65.

Wicker, A. W. (1969). Attitudes versus Actions: The Relationship of Verbal and Overt Behavioral Responses to Attitude Objects. Journal of Social issues, 25(4): 41-78.

Wilson, J., Tyedmers, P., Spinney, J. E. L. (2013). An Exploration of the Relationship between Socioeconomic and Well-Being Variables and Household Greenhouse Gas Emissions. Journal of Industrial Ecology, 17(6): 880-891.

World Bank. 2015. Data: CO2 Emissions (Metric Tons Per Capita). Washington, DC: The World Bank Group. URL: http://data.worldbank.org/indicator/EN.ATM. CO2E.PC (July 10, 2015).

Yale. (2015). Yale Program on Climate Change Communication. A Program of the Yale Center for Environmental Communication and the Yale School of Forestry and Environmental Studies. URL: http://climatecommunication.yale.edu/ (August 16, 2016).

Zalasiewicz, J., Waters, C. N., Barnosky, A. D., Cearreta, A., Edgeworth, M., Ellis, E. C., Gałuszka, A., Gibbard, P. L., Grinevald, J., Hajdas, I., Ivar do Sul, J., Jeandel, C., Leinfelder, R., McNeill, J. R., Poirier, C., Revkin, A., deB Richter, D., Steffen, W., Summerhayes, C., Syvitski, J. P. M., Vidas, D., Wagreich, M., Williams, M., Wolfe, A. P. (2015). Colonization of the Americas, 'Little Ice Age' Climate, and Bomb-Produced Carbon: Their Role in Defining the Anthropocene. The Anthropocene Review, 2(2): 117-127. 
Zhang, X., Luo, L., Skitmore, M. (2015). Household Carbon Emission Research: An Analytical Review of Measurement, Influencing Factors and Mitigation Prospects. Journal of Cleaner Production, 103: 873-883. 


\section{Appendix}

Table 3. Average and frequency information for the Alarmed including demographics, political ideology, neighborhood effects, household income, and climate beliefs.

\begin{tabular}{|c|c|c|c|}
\hline & \multicolumn{2}{|c|}{ Average or Frequency of Variable } & \multirow{2}{*}{$\begin{array}{l}\text { Significance of } \\
\text { Difference }\end{array}$} \\
\hline & Alarmed & Non-Alarmed & \\
\hline Median Age & $50 \mathrm{yrs}$ & $45 \mathrm{yrs}$ & $\mathrm{t}=-.886(\mathrm{p}=.376)$ \\
\hline \multicolumn{4}{|l|}{ Gender } \\
\hline$\%$ Male & $38.5 \%$ & $50.3 \%$ & \multirow[b]{2}{*}{$\chi^{2}=17.7(p=.000)$} \\
\hline$\%$ Female & $61.5 \%$ & $49.7 \%$ & \\
\hline \multicolumn{4}{|l|}{ Education } \\
\hline$\%$ High school or less & $33.5 \%$ & $46.8 \%$ & \multirow{4}{*}{$\chi^{2}=38.3(p=.000)$} \\
\hline \% Some college/Assoc. & $28.2 \%$ & $27.8 \%$ & \\
\hline \% Bachelor's degree & $22.7 \%$ & $17.8 \%$ & \\
\hline $\begin{array}{l}\text { \% Master's/above } \\
\text { professional, or doctoral }\end{array}$ & $15.7 \%$ & $7.6 \%$ & \\
\hline \multicolumn{4}{|l|}{ Race/Ethnicity } \\
\hline$\%$ White (Non-Hispanic) & $66.3 \%$ & $70.1 \%$ & \multirow{5}{*}{$\chi^{2}=3.6(p=.460)$} \\
\hline \% Black (Non-Hispanic) & $10.9 \%$ & $11.2 \%$ & \\
\hline \% Other (Non-Hispanic) & $6.1 \%$ & $5.2 \%$ & \\
\hline$\%$ Hispanic & $15 \%$ & $12.4 \%$ & \\
\hline $\begin{array}{l}\text { \% Two or more races } \\
\text { (Non-Hispanic) }\end{array}$ & $1.7 \%$ & $1.0 \%$ & \\
\hline \multicolumn{4}{|l|}{ Household } \\
\hline Household size & 2.47 persons & 2.55 persons & $\mathrm{t}=.975(\mathrm{p}=.330)$ \\
\hline Household income & $\begin{array}{c}\$ 50,000-\$ 59,999 \\
\text { (median cat selection) }\end{array}$ & $\begin{array}{c}\$ 50,000-\$ 59,999 \\
\text { (median cat.selection) }\end{array}$ & $\mathrm{t}=-.217(\mathrm{p}=.828)$ \\
\hline \multicolumn{4}{|l|}{ Political ideology } \\
\hline Very liberal & $15.7 \%$ & $4.0 \%$ & \multirow{6}{*}{$\chi^{2}=149.5(p=.000)$} \\
\hline Somewhat liberal & $32.1 \%$ & $18.7 \%$ & \\
\hline Moderate & $38.4 \%$ & $39.7 \%$ & \\
\hline Somewhat conservative & $10.9 \%$ & $26.1 \%$ & \\
\hline Very conservative & $2.8 \%$ & $10.6 \%$ & \\
\hline Item non-response & $0.1 \%$ & $0.9 \%$ & \\
\hline \multicolumn{4}{|l|}{ Neighborhood effects } \\
\hline CT median income & $\$ 55,278$ & $\$ 53,820$ & $\mathrm{t}=-1.04(\mathrm{p}=.297)$ \\
\hline CT \% BA degree & $30.79 \%$ & $27.13 \%$ & $\mathrm{t}=-3.38(\mathrm{p}=.001)$ \\
\hline MSA status & $86.7 \%$ & $83.0 \%$ & $\chi^{2}=2.95(p=.086)$ \\
\hline CT Pop. density & 6119.03 pers $/ \mathrm{mile}^{2}$ & $4612.46 \mathrm{pers} / \mathrm{mile}^{2}$ & $\mathrm{t}=-1.80(\mathrm{p}=.072)$ \\
\hline \multicolumn{4}{|c|}{ CCAMS belief segmentation } \\
\hline Alarmed & $18.0 \%$ & & \\
\hline Non-Alarmed & & $82.0 \%$ & \\
\hline All Totals / Sample Size & $100.0 \% / 380$ & $100.0 \% / 1727$ & \\
\hline
\end{tabular}

Source: Climate Change in the American Mind Survey (2008); US Census Bureau, American Community Survey 5-year Estimate, 2006-2010 (US Census Bureau, 2015). 


\title{
KULTURA, UGLJIČNI DIOKSID I KLIMATSKE PROMJENE: KLASNA ANALIZA VJEROVANJA U KLIMATSKE PROMJENE, INERTNOSTI ŽIVOTNOG STILA I OSOBNOG UGLJIČNOG OTISKA
}

\author{
Jean Léon Boucher
}

\begin{abstract}
Sažetak
Globalne klimatske promjene jedno su od najvažnijih pitanja današnjice a emisije ugljičnog dioksida među glavnih krivcima za postojeće stanje. Ranija su istraživanja pokazala da su emisije ugljičnog dioksida usko povezane s visinom prihoda kućanstava - kako unutar određene države tako i usporedbom izmecu država. Jedan od temeljnih razloga navedene veze izmedu prihoda i emisija ugljičnog dioksida istraživači pronalaze $u$ inertnosti životnog stila: nesposobnosti pojedinaca da izmijene svoje potrošačke navike zbog institucionaliziranih struktura, konteksta u kojima žive i vladajućih normi. Na reprezentativnom uzorku Sjedinjenih Američkih Država $(N=2107)$ provjerili smo korelaciju izmedu vjerovanja u klimatske promjene i odnosa izmectu prihoda i emisija ugljičnog dioksida (emisije se odnose na ugljični otisak izmjeren isključivo za osobnu mobilnost i način prehrane). Pronašli smo statistički značajne pozitivne korelacije izmedu vjerovanja u klimatske promjene i osobnog ugljičnog otiska kod samo jednog dijela populacije - onih koji su najzabrinutiji oko klimatskih promjena (18\% uzorka). Dodatno, potvrdili smo statistički značajnu pozitivnu korelaciju izmecu prihoda kućanstva i emisija ugljičnog dioksida - prihodi su se pokazali najjačim prediktorom. U radu predlažemo oporezivanje i ograničavanje kako prihoda tako i emisija ugljičnog dioksida.
\end{abstract}

Ključne riječi: osobni ugljični otisak, ekološko ponašanje, ekološki stavovi, inertnost životnog stila, vjerovanje u klimatske promjene

\section{KULTUR, KOHLENSTOFFDIOXID UND KLIMAWANDEL: KLASSENANALYSE DES GLAUBENS AN DEN KLIMAWANDEL, TRÄGHEIT DES LEBENSSTILS UND PERSÖNLICHER CO2-FUßABDRUCK}

\author{
Jean Léon Boucher
}

\begin{abstract}
Zusammenfassung
Der globale Klimawandel ist eine der wichtigsten Fragen der Gegenwart und die Kohlenwasserstoffemission eine der Hauptursachen dieses Zustands. Vorherige Forschungen haben gezeigt, dass die Koblenwasserstoffemission eng verbunden ist mit der Einkommenshöhe der Haushalte, sowohl innerhalb eines Staates als auch im Vergleich unter Staaten. Einen der Hauptgründe der genannten Verbindung zwischen Einkommen und Kohlenwasserstoffemission sehen die Forscher in Trägheit des Lebensstils: der Unfähigkeit des Einzelnen nämlich, seine Verbrauchergewohnheiten zu ändern infolge der institutionalisierten Strukturen, des Lebenskontextes und der vorherrschenden Normen.

An einem repräsentativen Muster der USA $(N=2107)$ haben wir die Korrelierung zwischen dem Glauben an die Klimaänderung und dem Verhältnis des Einkommens und der Kohlenwasserstoffemission geprüft (Emissionen beziehen sich ausschließlich auf den CO2-Fußabdruck für persönliche Mobilität und Ernährungsweise). Wir haben statistisch bedeutende positive Korrelierungen gefunden zwischen dem Glauben an den Klimawandel und dem persönlichen CO2-Fußabdruck bei nur einem Teil der Population - bei denjenigen nämlich, die sich wegen des Klimawandels am meisten Sorgen machen (18\% des Musters). Außerdem haben wir statistisch bedeutende positive Korrelierungen zwischen dem Haushaltseinkommen und den CO2-Emissionen bestätigt - die Einkünfte haben sich als der stärkste Prädiktor gezeigt. Deshalb schlagen wir Besteuerung und Begrenzung sowohl von Einkünften als auch von CO2-Emissionen vor.
\end{abstract}

Schlüsselwörter: persönlicher CO2-Fußabdruck, ökologisches Verhalten, Stellungnahmen zum Umweltschutz, Trägheit des Lebensstils, Glauben an den Klimawandel 